\title{
Rural population mixing and childhood leukaemia: effects of the North Sea oil industry in Scotland, including the area near Dounreay nuclear site
}

\author{
LJ Kinlen, F O’Brien, K Clarke, A Balkwill, F Matthews
}

\begin{abstract}
Objective-To determine if any excess of childhood leukaemia and non-Hodgkin's lymphoma was associated with certain striking examples of population mixing in rural Scotland produced by the North Sea oil industry.

Design-Details were traced for over 30000 workers involved in the construction of the large oil terminals in the Shetland and Orkney islands in northern Scotland or employed offshore. Home addresses of the 17160 Scottish residents were postcoded, integrated with census data, and then classified as urban or rural. Rural postcode sectors, ranked by proportion of oil workers, were grouped into three categories with similar numbers of children but contrasting densities of oil workers. The incidence of leukaemia and non-Hodgkin's lymphoma was examined in these rural (and also in urban) categories in the periods 1974-8, 1979-83 and 1984-8.
\end{abstract}

Setting-Scotland.

Subjects-Young people below age 25 .

Results-A significant excess of leukaemia and non-Hodgkin's lymphoma was found in 1979-83 in the group of rural home areas with the largest proportion of oil workers, following closely on large increases in the workforce. The area near the Dounreay nuclear installation, where an excess of leukaemia is already well known, was within the rural high oil category.

Conclusion-The findings support the infection hypothesis that population mixing can increase the incidence of childhood leukaemia in rural areas. They also suggest that the recent excess in the Dounreay-Thurso area is due to population mixing linked to the oil industry, promoted by certain unusual local demographic factors.

\section{Introduction}

Evidence has mounted that the incidence of childhood leukaemia can be increased by population mixing, particularly in a rural area. ${ }^{1-4}$ This implies an increase in contacts between susceptible and infected individuals for some unidentified transmissible agent whose transmission is more likely in areas of low population density where the prevalence of susceptible people tends to be higher than average. A striking example of rural population mixing has been produced in northern Scotland by the North Sea oil industry. The Sullom Voe oil terminal in Shetland, which can handle $70 \%$ of the United Kingdom's crude oil production, was Europe's largest construction site-moreover it is sited in Britain's remotest region.5 Many thousands of men were transported and housed in specially built camps, drawn from places as diverse as the sparsely populated Scottish highlands and the densely populated conurbations of Britain. Similar arrangements applied to the smaller terminal at Flotta in Orkney. In addition, offshore work involves many thousands of men travelling to Aberdeen from all over Britain, to be ferried to installations by helicopter. Few children live close to these work sites (and, obviously, none offshore), but the regular home visits of these workers might occasion indirect exposure of their home communities to any effects of the mixing in those unusual worksites. We therefore studied leukaemia and non-Hodgkin's lymphoma in young people in the rural home areas of workers at Scottish oil terminal and offshore sites.

\section{Methods}

OIL INDUSTRY WORKERS

We concentrated on the three largest groups of workers in the oil industry ("oil workers") in northern Scotland in the late 1970s: construction workers of the oil terminal at Sullom Voe (Shetland); construction workers of the Flotta oil terminal (Orkney); and offshore workers on rigs and platforms. We could not identify all such workers as complete records have not survived and instead used the closest approximations possible-namely, records incorporating home address of all those (more than 17000) attending the medical centre at the Sullom Voe oil terminal in Shetland during its construction phase (believed to represent a high proportion of all but short stay workers); 3500 construction workers at the Flotta oil terminal in Orkney (incomplete data); and more than 10000 offshore workers, being all those who obtained an offshore survival certificate (required for such work) in Scotland in the period from June 1976 (the earliest date for which records have not been destroyed) to 1980. Substantial sections of the three workforces were covered in this way. For the purposes of this study, the three groups of oil workers have been combined. Many of these workers lived outside Scotland, particularly in the Tyneside and Teesside areas of England. After eliminating duplication due to men working at more than one site, the postcodes of all Scottish addresses were determined.

\section{LEUKAEMIA AND NON-HODGKIN'S LYMPHOMA}

Details of leukaemia and non-Hodgkin's lymphoma in patients aged under 25 were provided by postcode sector by the Scottish Cancer Registration Scheme for the 1970s and 1980s (from the start of the North Sea oil industry). Expected numbers for each sector were calculated by multiplying the five year age specific population of each sector in different calendar periods (see below) by the corresponding Scottish incidence rates for these diseases.

Correspon 
STUDY CATEGORIES: AREAS AND PERIODS

By integrating the postcoded details of oil workers with census small area statistics by postcode sector we calculated the proportions of oil workers among economically active men (those in work at the time of the census) in each postcode sector of Scotland. "Urban" areas were arbitrarily defined as those postcode districts that embrace Dundee, Aberdeen, and Scotland's central industrial belt stretching from Edinburgh to the Firth of Clyde west of Glasgow. The remainder of Scotland was regarded as "rural." To estimate the proportion of oil workers needed to influence the incidence of childhood leukaemia in a rural population, we created three categories containing different proportions of oil workers but with similar populations of children. We ranked rural postcode sectors in ascending order of proportions of oil workers among economically active men. By accumulating the calculated expected numbers of cases of leukaemia and non-Hodgkin's lymphoma below age 15 we then created three categories with (as far as possible) similar expected numbers. The ranges of density of oil workers in these categories were $\leqslant 4.81$ oil workers per 1000 economically active men (low), ranges were also used to examine urban areas. Aberdeen was examined separately because of its special place in the North Sea oil industry.

The three periods mainly considered were $1974-8$, $1979-83$ and $1984-8$. The period $1979-83$ centres on a census year, and 1974-8 and 1984-8 are of similar length (1988 is the latest year for which cancer registration data were available). For the period 1974-8, populations for 1976 were used, estimated as the mean of the relevant age specific numbers from the 1971 and 1981 censuses. For 1984-8, postcode sector populations by age group in 1986 were estimated by adjusting the 1981 figures by the proportionate regional changes in the 1986 age specific estimates of the

TABLE I-Details of study categories

\begin{tabular}{|c|c|c|c|c|c|}
\hline \multirow[b]{2}{*}{ Type of area } & \multicolumn{4}{|c|}{ Oil workers } & \multirow[b]{2}{*}{$\begin{array}{l}\text { No of } \\
\text { economically } \\
\text { active men } \\
(1981)\end{array}$} \\
\hline & Category & $\begin{array}{c}\text { Density } \\
\text { (per } 1000 \\
\text { economically } \\
\text { active men) }\end{array}$ & No & $\begin{array}{c}\text { No in } \\
\text { Sullom Voe }\end{array}$ & \\
\hline \multirow[t]{2}{*}{ Rural } & $\begin{array}{l}\text { Low } \\
\text { Medium } \\
\text { High }\end{array}$ & $\begin{array}{c}0-4 \cdot 81 \\
4 \cdot 82-10 \cdot 56 \\
10 \cdot 57-330 \cdot 4^{\star}\end{array}$ & $\begin{array}{r}555 \\
1470 \\
5677\end{array}$ & $\begin{array}{r}291 \\
794 \\
2935\end{array}$ & $\begin{array}{l}208570 \\
196650 \\
182070\end{array}$ \\
\hline & & & 7702 & 4020 & 587290 \\
\hline \multirow[t]{2}{*}{ Urban (excluding Aberdeen city) } & $\begin{array}{l}\text { Low } \\
\text { Medium } \\
\text { High }\end{array}$ & $\begin{array}{c}0-4 \cdot 81 \\
4 \cdot 82-10 \cdot 56 \\
10 \cdot 57-40 \cdot 83\end{array}$ & $\begin{array}{r}390 \\
2832 \\
4274\end{array}$ & $\begin{array}{r}235 \\
1862 \\
3113\end{array}$ & $\begin{array}{l}129210 \\
377190 \\
285290\end{array}$ \\
\hline & & & 7496 & 5210 & 791690 \\
\hline Aberdeen city & High & $15 \cdot 55-75 \cdot 24$ & 1962 & 156 & 61760 \\
\hline
\end{tabular}

ॠ330.4 in Shetland; with the exception of certain tiny sectors, the highest mainland value was 56 . $4 \cdot 82-10.56$ (medium), and $\geqslant 10.57$ (high). These

registrar general's data. (When all sector populations estimated by this method were summed across ages $0-24$, the total was $0.56 \%$ below the published Scottish figure for 1986.) There was a substantial increase in terminal and offshore activity in $1977-8,{ }^{67}$ reaching unprecedented levels shortly afterwards. In terms of their potential effects, the three periods may therefore be seen as pre-mixing, early post-mixing, and later post-mixing.

\section{SPECIFIC INVESTIGATIONS}

The incidence of leukaemia and non-Hodgkin's lymphoma was also investigated with respect to factors that may influence the prevalence of individuals susceptible to infective agents or the intensity of exposure. These include relative isolation, taken as more than $20 \mathrm{~km}$ from urban areas ${ }^{8}$; social class, defined as the proportion of the population in the registrar general's classes I and II; density of children, taken crudely as the number of enumeration districts in a given sector having 100 or more children (postcode sectors are fairly large, and acreages of enumeration districts are not available); and increases from 1971 to 1981 in the numbers of men working away from home in the construction and energy industries ("recent oil impact measure"). This measure of increases in men working away from home is unduly conservative but is the closest possible from census data, being the numbers of men in these industries who were working outside their local government district of residence in 1981 minus all men in the construction industry in 1971, expressed as a percentage of economically active men in 1981 . (Details of men working outside their local government district in 1971 are not available.) It is relevant that these districts are large, in some cases similar to old counties, and that rural areas contained negligible numbers of oil workers in 1971 when the energy industry was not a census category.

\section{STATISTICS}

Significance levels (two sided) for the relative risks were calculated, based on an assumed Poisson distribution. Point estimates for the relative risks were computed by using the observed to expected ratios in the individual exposure groups. Confidence intervals for these were calculated on the basis of the associated binomial probability. ${ }^{9}$

\section{Results}

Table I shows details of the 17160 oil workers resident in Scotland, by category, together with the corresponding numbers of economically active men. Observed and expected numbers for leukaemia and non-Hodgkin's lymphoma were combined and are shown in table II for ages $0-4,5-14,15-24$, and $0-24$ by oil worker category in urban and rural Scotland and in

TABLE II-Observed (expected) numbers of cases of leukaemia and non-Hodgkin's lymphoma in young people by density of oil workers in urban and rural Scotland

\begin{tabular}{|c|c|c|c|c|c|c|c|c|}
\hline \multirow[b]{2}{*}{ Oil worker category } & \multicolumn{4}{|c|}{ Urban areas } & \multicolumn{4}{|c|}{ Rural areas } \\
\hline & $0-4$ years & $5-14$ years & $15-24$ years & $0-24$ years & $0-4$ years & $5-14$ years & $15-24$ years & $0-24$ years \\
\hline \multicolumn{9}{|c|}{ 1974-78 (pre-mixing period): } \\
\hline Low & $8(10.44)$ & $12(13.36)$ & $7(9 \cdot 38)$ & $27(33 \cdot 18)$ & $19(17.50)$ & $19(21.91)$ & $14(14 \cdot 86)$ & $52(54 \cdot 27)$ \\
\hline Medium & $43(35.06)$ & $43(42 \cdot 37)$ & $27(30 \cdot 50)$ & $113(107.93)$ & $19(17 \cdot 23)$ & $25(20.83)$ & $9(14 \cdot 18)$ & $53(52 \cdot 23)$ \\
\hline High & $24(33.58)$ & $37(41 \cdot 36)$ & $38(29 \cdot 66)$ & $99(104 \cdot 60)$ & $17(16 \cdot 19)$ & $23(19 \cdot 19)$ & $16(12 \cdot 42)$ & $56(47.79)$ \\
\hline Total & $75(79.08)$ & $92(97.09)$ & $72(69.54)$ & $239(245 \cdot 71)$ & $55(50.92)$ & $67(61.93)$ & $39(41 \cdot 40)$ & $161(154 \cdot 29)$ \\
\hline \multicolumn{9}{|c|}{ 1979-83 (early post-mixing period): } \\
\hline Low & $9(9 \cdot 02)$ & $7(9 \cdot 08)$ & $9(10 \cdot 19)$ & $25(28 \cdot 29)$ & $11(15 \cdot 69)$ & $15(15.50)$ & $20(15 \cdot 87)$ & $46(47 \cdot 05)$ \\
\hline Medium & $23(29 \cdot 23)$ & $25(27 \cdot 60)$ & $32(32 \cdot 22)$ & $80(89.05)$ & $15(16 \cdot 11)$ & $18(14.95)$ & $14(15 \cdot 45)$ & $47(46 \cdot 52)$ \\
\hline High & $26(28 \cdot 33)$ & $27(27.05)$ & $28(31 \cdot 36)$ & $81(86 \cdot 74)$ & $31(16 \cdot 60)^{\star \star}$ & $17(14 \cdot 83)$ & $16(13.93)$ & $64(45 \cdot 37)^{\star \star}$ \\
\hline Total & $58(66 \cdot 58)$ & $59(63.73)$ & $69(73 \cdot 77)$ & $186(204.08)$ & $57(48 \cdot 40)$ & $50(45 \cdot 28)$ & $50(54 \cdot 25)$ & $157(138.94)$ \\
\hline \multicolumn{9}{|c|}{ 1984-88 (later post-mixing period): } \\
\hline Low & $12(9 \cdot 42)$ & $9(9 \cdot 07)$ & $9(12 \cdot 76)$ & $30(31 \cdot 25)$ & $15(16 \cdot 33)$ & $17(15 \cdot 84)$ & $16(19 \cdot 39)$ & $48(51 \cdot 56)$ \\
\hline Medium & $30(30 \cdot 33)$ & $29(27 \cdot 40)$ & $35(39 \cdot 48)$ & $94(97 \cdot 20)$ & $17(16 \cdot 55)$ & $15(15.59)$ & $22(19 \cdot 21)$ & $54(51 \cdot 35)$ \\
\hline High & $27(29 \cdot 45)$ & $22(27.41)$ & $48(38.72)$ & $97(95 \cdot 58)$ & $18(16.91)$ & $19(15.74)$ & $17(17 \cdot 42)$ & $54(50.06)$ \\
\hline Total & $69(69 \cdot 20)$ & $60(63.88)$ & $92(90.96)$ & $221(224 \cdot 03)$ & $50(49 \cdot 79)$ & $51(47 \cdot 17)$ & $55(56.02)$ & $156(152.97)$ \\
\hline
\end{tabular}


TABLE III-Registrations for leukaemia and non-Hodgkin's lymphoma in 1979-83 in children aged 0-4 years

\begin{tabular}{|c|c|c|c|c|}
\hline \multirow[b]{2}{*}{ Oil worker category } & \multicolumn{3}{|c|}{ No of cases } & \multirow{2}{*}{$\begin{array}{c}\text { Relative risk } \\
\text { (95\% confidence } \\
\text { interval) }\end{array}$} \\
\hline & Observed & Expected & $\mathrm{O} / \mathrm{E}$ & \\
\hline Low & 11 & $15 \cdot 69$ & $0 \cdot 70$ & 1.00 \\
\hline Medium & 15 & $16 \cdot 11$ & 0.93 & $1.33(0.55$ to 3.22$)$ \\
\hline High & 31 & $16 \cdot 60$ & 1.87 & $2.67(1.30 \text { to } 5.88)^{\star}$ \\
\hline $\begin{array}{l}\text { Excluding area within } 25 \mathrm{~km} \text { of } \\
\text { Dounreay }\end{array}$ & 28 & $16 \cdot 26$ & $1 \cdot 72$ & $2.46(1.20 \text { to } 5.44)^{\star}$ \\
\hline
\end{tabular}

${ }^{\star} p<0.01$ for trend.

TABLE IV-Annual incidence per 100000 of leukaemia and nonHodgkin's lymphoma by age in certain rural and urban categories by calendar period. Observed numbers are given in parentheses

Age

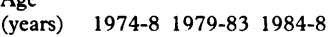

Rural high oil worker category

(0) $13(6) \quad 2(1)$

$\begin{array}{ccc}6(3) & 9(4) & 2(2) \\ 9(4) & 38(17) & 15(7)\end{array}$

4 (6) $\quad 5(2) \quad 12(5)$

$5(2) \quad 5(2) \quad 9(4)$

Rural low and medium

oil worker categories

$\begin{array}{lll}3(3) & (0) & 6(6)\end{array}$

$10(10) \quad 5(4) \quad 7(6)$

$\begin{array}{lll}9(9) & 9(8) & 6(5) \\ 12(11) & 13(10) & 13(11)\end{array}$

$6(6) 5(4) \quad 5(4)$

All urban categories

$\begin{array}{lll}3(7) \quad 1(2) & 3(6)\end{array}$

$\begin{array}{lll}3(7) & 1(2) & 3(6) \\ 6(15) & 3(5) & 6(11)\end{array}$

$\begin{array}{rcr}6(15) & 3(5) & 6(11) \\ 10(23) & 13(22) & 11(20)\end{array}$

$6(12) 10(16) \quad 6(11)$

$\begin{array}{rrr}8(18) & 8(13) & 12(21)\end{array}$

the three periods. Of 18 categories only the rural high oil group in 1979-83, the early post-mixing period, showed a significant excess. This reflects an excess at ages $0-4$ ( 31 observed, 16.60 expected) and is associated with a significant trend $(p<0.01)$ across the three rural categories, assuming a log linear model (table III). It is largely due to leukaemia (27 observed, $15 \cdot 16$ expected), mainly acute lymphatic leukaemia. The rural high oil category showed no significant excess in the other two periods in any age group, nor was there any (significant) excess in any period in the rural low or medium groups or any urban group. Incidence was also examined in 1969-73 (data not shown), but as in 1974-8 there was no excess in the rural high oil group. An excess at 0-4 years was present in the high category when the rural oil categories were reconstituted on the basis of ranked prevalence of workers at Sullom Voe only (29 observed, 16.45 expected; $p<0.01$ ), at Flotta only (24 observed, expected 16.27; $\mathrm{p}<0.08)$, and offshore (29 observed, expected $16.55 ; \mathrm{p}<0.01$ ).

When examined by single years of age from 0 to 4 (table IV), the rural high oil category showed excesses below age 1 , at age 1 , and particularly at age 2 , when annual incidence peaked at 38/100 000/year. This peak at age 2 contrasts with that at age 3 (in all three periods) in all urban areas and in the rural low and medium areas, as was found in the rural high oil group in the earlier period, 1974-8. In 1984-8, when incidence at ages $0-4$ had declined, the rural high oil group continued to show a peak at age 2. Details of father's occupation in cancer registration and mortality records did not suggest any excess of oil related jobs among the fathers of cases living in rural high oil areas. Moreover, a comparison of the names of all rural oil workers with those of fathers of children with leukaemia or nonHodgkin's lymphoma in 1979-83 (ascertained for another study) produced only a single match.

Incidence in the rural high oil category was examined in more isolated ( $>20 \mathrm{~km}$ from urban areas) and less isolated sectors, and at higher and lower levels of certain factors, for which the division was made after ranking the sectors on the factor (disregarding isolation) at the point that as closely as possible halved the cumulative expected values at ages $0-14$. The increased incidence at ages $0-4$ was restricted to postcode sectors more than $20 \mathrm{~km}$ from urban areas, where it was greater in sectors of higher social class (table V). There was also some indication of a higher incidence in sectors with a higher child density measure both at ages $0-4$ and 5-24, and at both greater and lower degrees of isolation. In more isolated areas, where increases of construction workers working away from home in the 1970s (the recent oil impact measure) were greater, there was a higher incidence of leukaemia and non-Hodgkin's lymphoma at ages 5-24 (but not at $0-4)$ than in remaining areas. When these differences were investigated by this approach using three subgroups of similar size, the recent oil impact measure in more isolated areas showed a significant trend at ages $5-24(\mathrm{p}<0.01$; table VI). Social class in more isolated areas showed a slight (but non-significant) trend in both age groups (table VI).

TABLE V-Observed and expected numbers of cases of leukaemia and non-Hodgkin's lymphoma in rural high oil sectors

\begin{tabular}{|c|c|c|c|c|c|c|c|c|c|}
\hline \multirow[b]{2}{*}{ Age (years) } & \multirow[b]{2}{*}{ Half* } & \multicolumn{4}{|c|}{$\leqslant 20 \mathrm{~km}$ from urban area } & \multicolumn{4}{|c|}{$>20 \mathrm{~km}$ from urban area } \\
\hline & & Observed & Expected & $\mathrm{O} / \mathrm{E}$ & $\begin{array}{c}\text { Relative risk } \\
\text { (95\% confidence } \\
\text { interval) }\end{array}$ & Observed & Expected & $\mathrm{O} / \mathrm{E}$ & $\begin{array}{l}\text { Relative risk } \\
\text { (95\% confidence } \\
\text { interval) }\end{array}$ \\
\hline \multicolumn{10}{|l|}{ Social class: } \\
\hline \multirow{2}{*}{$0-4$} & Lower & 9 & $4 \cdot 204$ & $2 \cdot 14$ & 1.00 & 6 & $4 \cdot 056$ & 1.48 & 1.00 \\
\hline & Higher & 2 & 3.869 & 0.52 & $0.24(0.03$ to 1.17$)$ & 14 & $4 \cdot 473$ & $3 \cdot 13$ & $2.12(0.78$ to 6.71$)$ \\
\hline \multirow{2}{*}{$5-24$} & Lower & 9 & $7 \cdot 436$ & $1 \cdot 12$ & 1.00 & 8 & $7 \cdot 226$ & $1 \cdot 11$ & 1.00 \\
\hline & Higher & 6 & $6 \cdot 295$ & 0.95 & $0.79(0.22$ to 2.45$)$ & 10 & $7 \cdot 810$ & 1.28 & $1.16(0.42$ to 3.41$)$ \\
\hline \multicolumn{10}{|c|}{ Density of children } \\
\hline \multirow[t]{2}{*}{$0-4$} & Lower & 4 & 3.824 & 1.05 & 1.00 & 11 & $5 \cdot 123$ & $2 \cdot 15$ & 1.00 \\
\hline & Higher & 7 & $4 \cdot 249$ & 1.65 & $1.57(0.40$ to 7.37$)$ & 9 & $3 \cdot 406$ & $2 \cdot 64$ & $1.23(0.45$ to 3.27$)$ \\
\hline \multirow{2}{*}{$5-24$} & Lower & 6 & 6.967 & 0.86 & 1.00 & 8 & $9 \cdot 133$ & $0 \cdot 88$ & 1.00 \\
\hline & Higher & 9 & $6 \cdot 764$ & 1.33 & $1.55(0.50$ to 5.27$)$ & 10 & 5.903 & 1.69 & $1.93(0.70$ to 5.70$)$ \\
\hline \multicolumn{10}{|c|}{ Recent oil impact measure: } \\
\hline \multirow[t]{2}{*}{$0-4$} & Lower & 5 & $3 \cdot 145$ & 1.59 & 1.00 & 13 & $5 \cdot 113$ & 2.54 & 1.00 \\
\hline & Higher & 6 & 4.928 & $1 \cdot 22$ & $0.77(0.19$ to 3.15$)$ & 7 & $3 \cdot 416$ & 2.05 & $0.81(0.27$ to 2.20$)$ \\
\hline \multirow[t]{2}{*}{$5-24$} & Lower & 7 & 6.059 & $1 \cdot 16$ & 1.00 & 7 & $9 \cdot 184$ & 0.76 & 1.00 \\
\hline & Higher & 8 & $7 \cdot 672$ & $1 \cdot 04$ & $0.90(0.28$ to 2.88$)$ & 11 & $5 \cdot 852$ & $1 \cdot 88$ & $2.47(0.86$ to 7.51$)$ \\
\hline
\end{tabular}

ॠThe division into lower and higher was at the closest point possible to halving the total cumulative expected values (for ages $0-14$, for the two distance categories combined) ranked on the relevant measure.

TABLE VI-Effect of recent oil impact measure and social class on leukaemia and non-Hodgkin's lymphoma in rural high oil sectors $>20 \mathrm{~km}$ from urban areas

\begin{tabular}{|c|c|c|c|c|c|c|c|c|}
\hline & \multicolumn{4}{|c|}{ Age $0-4$ years } & \multicolumn{4}{|c|}{ Age $5-24$ years } \\
\hline & Observed & Expected & $\mathrm{O} / \mathrm{E}$ & $\begin{array}{c}\text { Relative risk } \\
\text { (95\% confidence } \\
\text { interval) }\end{array}$ & Observed & Expected & $\mathrm{O} / \mathrm{E}$ & $\begin{array}{c}\text { Relative risk } \\
(95 \% \text { confidence } \\
\text { interval) }\end{array}$ \\
\hline \multicolumn{9}{|l|}{ Recent oil impact measure: } \\
\hline Low & 10 & 3.74 & $2 \cdot 67$ & 1.00 & 3 & $6 \cdot 85$ & 0.44 & 1.00 \\
\hline Medium & 5 & $2 \cdot 98$ & 1.68 & $0.63(0.17$ to $2 \cdot 02)$ & 7 & $5 \cdot 17$ & 1.35 & $3.09(0.70$ to 18.61$)$ \\
\hline High & 5 & $1 \cdot 81$ & $2 \cdot 76$ & $1.03(0.27$ to 3.33$)$ & 8 & 3.02 & $2 \cdot 64$ & $6.04(1.45 \text { to } 35.12)^{\star}$ \\
\hline $\begin{array}{l}\text { Excluding } \\
\text { area within } 25 \mathrm{~km} \text { of }\end{array}$ & 2 & 1.47 & 1.36 & $0.51(0.05+0.39)$ & 5 & 2.00 & 2.50 & \\
\hline \multicolumn{8}{|l|}{ Social class: } & $5 \cdot 70(1 \cdot 11 \text { to } 36 \cdot 70)^{\star}$ \\
\hline Low & 4 & 2.92 & 1.37 & 1.00 & 5 & $5 \cdot 17$ & 0.97 & $1 \cdot 00$ \\
\hline Medium & 8 & 3.45 & $2 \cdot 32$ & $1.69(0.45$ to 7.62$)$ & 7 & 6.00 & $1 \cdot 17$ & $1.20(0.33$ to 4.85$)$ \\
\hline High & 8 & $2 \cdot 16$ & $3 \cdot 71$ & $2 \cdot 71(0.72$ to $12 \cdot 18)$ & 6 & 3.86 & 1.55 & $1.61(0.41$ to 6.60$)$ \\
\hline
\end{tabular}




\section{Discussion}

The hypothesis underlying this study was confirmed by finding a significant increase of childhood leukaemia in those rural areas of Scotland that were most affected by population "mixing" associated with the North Sea oil industry. Moreover, the effect occurred in the early post-mixing period and mainly in the $0-4$ age group, in keeping with findings in rural new towns in their early growth period. ${ }^{2}$ There can be concern in a study of this type that multiple testing may have resulted in certain conclusions being due to chance findings. However, the prior hypothesis led us to the findings in the rural high oil worker category (table II, both for all ages and the 0-4 age group. The only multiple testing therefore is within the time periods after population mixing (a total of two cells). However, the unusual nature of the mixing itself, as well as the areas it affected, warrants further discussion.

\section{MIXING: WORK SITES AND CAMPS}

Much has been written about the technological challenge of North Sea oil, said to be second only to the American space programme in scale. The development of this industry by 1981 (costing $£ 25000 \mathrm{~m}$ at 1980 prices) made a great impact on northern Scotland, a region of longstanding unemployment and depopulation. The building of oil terminals and platforms in the area, together with work offshore, provided unprecedented opportunities for employment. The most extensive operation was the construction in Britain's remotest region, Shetland, of the Sullom Voe oil terminal, the largest such site in Europe. The workforce (well over 20000 men) contained many from the Highlands and Islands, though the largest numbers were drawn from industrial parts of Scotland (Clydeside) and England (Tyneside and Teesside) that were severely affected by unemployment.

For all this to take place in so remote an area required not only payment of high wages but elaborate logistic arrangements on a massive scale, particularly with the strict conditions laid down by the Shetlands Islands Council to protect both the environment and the local way of life. These conditions severely limited off site recreation. Non-local workers were transported by plane and housed in large, specially built camps or in adjacent accommodation ships. Work hours were long, 10-12 hours per day, $6 \frac{1}{2}$ days a week, with a one week break taken away from the islands every four weeks. ${ }^{5}$ Weather was often poor, and recreation centred around the bars provided. The high effective population density was further increased, as on any construction site, by the frequent arrival of new workers as others left. Conditions were often crowded. The bringing together of workers was therefore not only on a larger scale but also more continuous than at other oil industry sites, including the isolated platform construction yards at Kishorn, Nigg, and Ardeseir in Highland Region, where many workers travelled from home daily or at least went home at weekends. These differences may be significant given the potency of large and relatively prolonged aggregations for producing epidemics in experiments. ${ }^{10}$

The workforce at Sullom Voe increased from around 1500 early in 1977 to over 6500 in 1979 and over 7200 in 1980; in 1981 the numbers fell to over 3000 with further declines thereafter. ${ }^{6}$ These numbers are exceptional for a construction site. Indeed a survey found that few such sites in rural Britain over the past 45 years reached even 3000 . (Sellafield is the most striking exception in the numbers of nuclear and construction workers working together on the same site over most of a 40 year period.) Oil related activity in the North Sea also increased at this time, and helicopter flights to offshore sites reached record numbers in $1978 .^{7}$ Such activity would further pro- mote contacts between individuals either susceptible to or infected with micro-organisms.

\section{LEUKAEMIA}

Ages 0-4-Leukaemia in Scottish rural areas showed a peak slightly later than in urban areas, at age 3 instead of age 2 . This may be due to the very low population density-below 0.03 per acre; similar (slight) differences between rural and urban areas are well known in certain childhood infectious diseases. " In the rural high oil category, where incidence increased significantly in 1979-83 (table II), the peak moved during that period to age 2 as in urban areas, remaining there in 1984-8; in other rural areas it continued to be at age 3 . The recent peak at age 2 in the rural high oil category might therefore be seen as an "urbanising" effect. Within this category, incidence at ages $0-4$ was greatest in areas of relative isolation and higher social class (table VI) as in another recent study. ${ }^{8}$ Here the prevalence of people susceptible to infectious agents would tend to be higher than in urban areas or in adjacent rural areas, which show no excess (tables II and VI).

Ages 5-24-There was no excess of leukaemia and non-Hodgkin's lymphoma at ages 5-24 in the rural high oil category. However, their incidence did show a highly significant trend with increasing oil impact measure among rural high oil sectors $(p<0.01$; table V). All this is consistent with the absence of any effect of oil work in urban areas (table II): rural post code sectors already supporting many construction workers (and Highlands Region has one of the highest levels of such workers in Britain) would be expected to be less affected by oil work than similar areas without such earlier "exposure" (that is, those in which the recent impact score was high). Areas with a relatively high density of children also seemed to have a higher incidence (table V), but a combined analysis was dominated by the recent oil impact measure. The absence of an increase [in cases of leukaemia] in the rural high oil category overall in 1979-83 is due to a deficiency that is almost significant in areas with a lower child density or a lower oil impact score-and which was not present in the previous period, 1974-8. Deficiencies at ages 5-24 were noted in new towns and the possibility was considered that they were due to immunising effects of a milder epidemic of the underlying infection. ${ }^{2}$ If they were not due to chance, however, this may apply here. The subgroup analyses are, to a certain extent exploratory.

\section{COMMUNICABLE DISEASES}

A severe epidemic of measles among local people in Shetland occurred in $1977-8$ with more than $30 \%$ of people affected aged over 14 and $10 \%$ aged over $24 .{ }^{12}$ Conditions at Sullom Voe were considered to have contributed to this epidernic as well as to unusual outbreaks of whooping cough, scarlet fever, and influenza (J D MacGregor, International Epidemiological Association, Edinburgh, 1981). ${ }^{13}$ The role of large aggregations of individuals for appreciable periods is probably of central importance here. Such aggregations not only promote transmission of microorganisms but through repeated exposure allow large doses of these. Large doses may be particularly important in relation to diseases that are uncommon responses to infection, such as feline leukaemia.

\section{ASCERTAINMENT OF OIL WORKERS}

Construction workers at the Sullom Voe oil terminal formed the largest group in this study. The proportion of the workforce covered by medical records (the source of our data) is probably greater than on most sites because a visit to the medical centre was one of the few legitimate reasons for breaking off work, so often 
made irksome by harsh weather. The other two groups were also not fully ascertained (in particular offshore workers who obtained their survival certificate before mid-1976). It is relevant, however, that their proportions in the populations were used only to rank the sectors (that is, for internal comparison). When we grouped the sectors approximately into local government districts and then ranked them on density of oil workers, this ranking coincided with that based on data for offshore workers in the 1981 census, ${ }^{14}$ suggesting that our data was not affected by geographic bias.

The rural high oil category showed broadly similar excesses whether defined on the basis of all oil workers or of those only at Sullom Voe, at Flotta, or offshore. This probably reflects the fact that all such work tended to attract men from similar areas-those that were conveniently situated or with low levels of local employment. The excesses in the analyses of Flotta or offshore may therefore be indirectly due to the effects of Sullom Voe.

The above findings on childhood leukaemia provide further evidence for horizontal transmission of some underlying infection of which leukaemia is a rare response $\mathrm{e}^{1-415}$ but made more likely in conditions of heavy exposure to the relevant agent, as in feline leukaemia. ${ }^{2}$ They also suggest that the relevant agent (or agents) can be transmitted among adults, and thence to children, as suggested by other recent work involving occupational settings. ${ }^{34}$ The excess of leukaemia and non-Hodgkin's lymphoma was not concentrated in the children of oil workers themselves, consistent with this being a community (or "herd") effect. The effects of the oil industry observed in this study are also consistent with long established observations on both experimental and human epidemics which Topley summarised 50 years ago as indicating that outbreaks of many infective diseases can be produced simply by "movements of susceptible and infected hosts in relation to one another, and aggregations or dispersals of human or animal herds." ${ }^{10}$

\section{DOUNREAY-THURSO AREA}

Among the rural areas with a high proportion of oil workers is the Dounreay-Thurso area, where a recent excess of childhood leukaemia is well known. ${ }^{16-18}$ The relation of this excess to the present study has a rather complicated history - with the excess near Sellafield, it originally suggested the population mixing hypothesis, but what was then in mind was the mixing connected with the nuclear industry; an analogy with a new town was drawn.' Subsequent studies have supported the hypothesis that population mixing can influence the incidence of childhood leukaemia. ${ }^{2-4}$ At the start of the present study and, indeed, until its analysis stage we did not associate the Dounreay-Thurso area with the oil industry, and finding that it contained a high proportion of oil workers was unexpected.

The 20 year interval between the first influx of nuclear workers in the late 1950 s and the cluster of cases near Dounreay beginning in 1979 could not readily be explained since the excesses usually followed fairly quickly on other types of population mixing. ${ }^{1-4}$ On the other hand, it would be incorrect to suppose that the first influx of nuclear workers in Thurso did not produce the twofold or greater increase noted in rural new towns: the only two cases at ages 0-14 in the period 1951-67 occurred in the five years following the influx in 1958 (expected 0.41 ; not significant). The well known excess of leukaemia began around 1979, at the same time as the increases found by this study in rural areas far removed from any nuclear installationbut all affected by population mixing associated with the oil industry. The (second) Dounreay-Thurso excess therefore followed closely on a striking example of population mixing.

\section{Leukaemia}

The excess of leukaemia and non-Hodgkin's lymphoma at ages $0-4$ in 1979-83 in the area within $25 \mathrm{~km}$ of Dounreay was appreciable $(8 \cdot 8$-fold), only six sectors in the rural high oil category having higher values (from $10 \cdot 4$-fold to 500 -fold). The excess at ages $5-24$ in this area is particularly noticeable and persistent, continuing up to 1988 . The relation with the recent oil impact measure (table VI) has obvious relevance here and also to why all the Thurso cases are in the west of the town, with none in the east: west Thurso is largely composed of nuclear workers not native to the area (locally known as "atomics"), making it until about 10 years ago rather separate from the rest of the town. Compared with sector KW14.8 covering the east part of the town, a smaller proportion of residents in sector KW14.7, which covers the west part, worked in the construction industry in the pre-oil era (table VII). Indeed, the east part of Thurso has a tradition of "travelling workers"-men regularly working away from home on construction. The availability of work at terminals just to the north led to a much greater increase in construction workers $(82 \%$ compared with $18 \%$ ) in the western sector (KW 14.7) than in the eastern sector (KW 14.8), so that by 1981 their levels had become similar. The recent oil impact was therefore greater in the west, which had twice as high a rank as the east (table VII). Also relevant may be the greater density of children in west Thurso, given the evidence suggesting such an effect (table V) and its importance in epidemics. ${ }^{10111920}$ Within the rural high oil category only three (small) sectors more than $20 \mathrm{~km}$ from urban areas had a higher rank than west Thurso when the recent oil impact and child density scores were combined.

In contrast, east Thurso (with no cases) may be seen as resembling the urban areas in our study in which the incidence of leukaemia was unaffected by the oil industry. The fewer susceptible people in urban areas would reflect the prior sporadic exposure to the widespread relevant agent, which would make them less vulnerable to an epidemic caused by new and sudden population mixing.

\section{Intensity of exposure: incomers}

The factor that may be decisive in explaining why the oil industry produced in west Thurso so great and prolonged an excess at ages 5-24 is the large number of incomers already associated with the nuclear industry. (An appreciable increase had also occurred in the late 1970 s in the numbers of US servicemen and their families in the area.) The 1971 census showed that the relevant postcode sector held almost the highest pro-

TABLE VII-Leukaemia and non-Hodgkin's lymphoma 1979-88 in Thurso and certain demographic factors in Thurso area

\begin{tabular}{|c|c|c|}
\hline & $\begin{array}{l}\text { West Thurso } \\
\text { (post code } \\
\text { sector } \\
\text { KW14.7) }\end{array}$ & $\begin{array}{c}\text { East Thurso } \\
\text { (post code } \\
\text { sector } \\
\text { KW 14.8) }\end{array}$ \\
\hline \multicolumn{3}{|c|}{$\begin{array}{l}\text { Observed to expected ratios (observed lexpected number of cases) of } \\
\text { leukaemia and non-Hodgkin's lymphoma* }\end{array}$} \\
\hline Ages 0-4 & $3 \cdot 1(1 / 0 \cdot 32)$ & $0(0 / 0 \cdot 16)$ \\
\hline Ages 5-24 & $8.7(5 / 0.58)$ & $0(0 / 0 \cdot 34)$ \\
\hline \multicolumn{3}{|c|}{ Demographic factors in Thurso areat } \\
\hline$\%$ Social classes I and II & 44 & 28 \\
\hline Rank‡ & 106 & 57 \\
\hline $\begin{array}{l}\text { Rank of recent oil impact measure } \\
\% \text { Increase in construction workers }\end{array}$ & 99 & 48 \\
\hline $1971-815$ & 80 & 18 \\
\hline$\%$ Born outside Scotland (1971) & 23 & $<10$ \\
\hline Rankł & 122 & 56 \\
\hline
\end{tabular}

^Data for part of postcode sector in parish of Thurso. Data for whole of sector.

$\ddagger$ Among 126 rural high oil sectors (lowest 1 , highest 126). †Among 126 rural high oil sectors (lowest 1 , highest
fAmong economically active men relative to 1981 . 
portion (23\%) of residents not born in Scotland of any sector in the rural high oil worker category, and indeed one of the highest in Scotland. Children who moved into west Thurso from other (and often distant) places would have been exposed quite suddenly (at school and elsewhere) to an unusual infective burden. Any such move makes probable the sudden exposure to new agents (or at least new strains) to which children born in the area, even if their parents had moved in, would already have developed some immunity. In the case of west Thurso such effects were likely to be compounded by the scale of exposure to infections among other incoming children, including possibly the infection of which childhood leukaemia is postulated to be a rare consequence. In a recent study of schools within $25 \mathrm{~km}$ of Dounreay, the proportion of incomers (born outside the county) among children was highest (namely, $50 \%$ ) for the birth cohort 1969-74 (R Black, personal communication). ${ }^{21}$ The proportion would have been even higher in the Pennyland Estate in west Thurso, for it was built by the nuclear authority specifically for incomers. All the cases of leukaemia in Thurso were centred on this estate, which lies just within $12.5 \mathrm{~km}$ of Dounreay, so that the excess there was much higher than in the next cumulative zone, which included the eastern half of the town (within $16.6 \mathrm{~km}$ ), a difference that has been the subject of much comment. ${ }^{18}$ It may not be a coincidence, therefore, that four of the five individuals who developed leukaemia at ages 5-24 in Thurso in the years 1979-88 were incomers-and also that four were born in the years 1969-74, the birth cohort with the greatest proportion of incomers. All three children with leukaemia at ages $0-4$ within $25 \mathrm{~km}$ of Dounreay were born in the area. The absence of cases in west Thurso above age 4 among children born locally may at least partly reflect the immunity conferred by their recent exposure at earlier ages.

As mentioned previously, in its unusual level of incomers west Thurso resembles a new town, albeit on a smaller scale. Here, this earlier population mixing would have represented a leukaemogenic influenceand in a part of the town in which shortly afterwards a second and different type of mixing was occasioned by the oil industry. Other evidence has suggested that a double influence operates in the development of leukaemia at ages 5-24, part early, the other late ${ }^{15}$ (possibly analogous to the way that early and persisting pestivirus infection in cattle alters the response to later infection by a different strain). ${ }^{22}$ The probable importance of large doses of the relevant agent (from either repeated exposures or particularly heavy exposures) has been emphasised previously in relation to childhood leukaemia. ${ }^{2}$ This is established in feline leukaemia, of which the greatly increased incidence in households with many cats is due mainly to exposure of kittens to large doses of a virus that usually causes merely an immunising infection. ${ }^{23}$ However, older cats are also at risk if introduced into those special households, but the exposure has usually to be longer. ${ }^{24}$ The cases of leukaemia in Thurso at ages 5-24 seem to be analogous, for these occurred later (in 1983-8) than those at ages 0-4 (1980-1).

We cannot test independently the relevance of the high proportion of children not born locally in the isolated area that is west Thurso since no area within the rural high oil category is known to approach its high level. However, the only area (comprising three adjacent sectors) in this category with a comparable proportion not born in Scotland (though it is much less isolated) also showed an excess in the period 1979-83 at ages 5-24 ( 2 cases observed, 0.54 expected).

Previous studies have not investigated the role of population mixing in the Dounreay-Thurso area, though they have shown that the excess of leukaemia and non-Hodgkin's lymphoma there cannot be attributed to paternal nuclear employment or irradiation before the child's conception. ${ }^{25}$ Furthermore, other evidence weighs strongly against radioactive discharges as the cause. ${ }^{26}$ The present findings suggest that the excess is due to the population mixing associated with the oil industry causing an epidemic of the infection, of which childhood leukaemia is an uncommon response. Certain factors specific to the Dounreay-Thurso area would have tended to promote transmission and heavy exposure.

We thank Dr Iain Macaulay of British Petroleum, Dyce, Aberdeen, for providing access to records of the Sullom Voe Medical Centre; Sister Carol Fitzgerald, Sister M Drosso, Helen Wilkes, Wendy Metcalfe, and Marjorie Macleod for help in data extraction; Fiona Smith, Davina Patrizio, Susan Hill, and Janette Wallis for secretarial help; and Jan Warner and Dr Roger Black of the Scottish Cancer Registration Scheme for cancer registration details. We also thank Dr W Pyle and Mr David Sinclair of Flotta, Professor J N Norman and John Brebner of the Robert Gordon Institute in Aberdeen, the managers of the Sullom Voe and Flotta oil terminals, and Mr Falconer Waters of Thurso for their help. We are also grateful to Dr Freda Alexander, Dr Paula Cook-Mozaffari, and Helen Wilkes for their comments on the paper.

1 Kinlen L. Evidence for an infective cause of childhood leukaemia: comparison of a Scottish new town with nuclear reprocessing sites in Britain. Lancet 1988;ii:1323-7.

2 Kinlen LJ. Evidence from population mixing in British new towns 1946-85 of an infective basis for childhood leukaemia. Lancet 1990;336:577-82.

3 Kinlen LJ, Hudson C, Stiller C. Contacts between adults as evidence for an infective origin of childhood leukaemia: an explanation for the excess near nuclear establishments in west Berkshire? Br $\mathcal{F}$ Cancer 1991;64:549-54

4 Kinlen LJ, Hudson C. Childhood leukaemia and poliomyelitis in relation to military encampments in England and $W$ ales in the period of national military service 1950-63. BMF 1991;303:1357-62.

5 Carr BJ, Williamson JL. The Sullom Voe success story. Proceedings of the Institution of Mechanical Engineers 1982;196:239-58.

6 Project payroll by areas of work. Sullom Voe Scene. 1981; No 47 (December): 11. (Aberdeen: British Petroleum.)

7 Alvarez A. Offshore: a North Sea journey. London: Hodder and Stoughton, 1986.

8 Alexander FE, Ricketts TJ, McKinney PA, Cartwright RA. Community lifestyle characteristics and risk of acute lymphoblastic leukaemia in children. Lancet 1990;336:1461-5.

9 Breslow NE, Day NE. Statistical methods in cancer research. Vol 2. The design and analysis of cohor studies. Lyons: International Agency for Research on Cancer, 1987:95. (IARC scientific publications No 82.)

10 Topley WWC. The biology of epidemics. Proc $R$ Soc London 1942;130:337-59.

11 Anderson RM, May RM. Directly transmitted infectious diseases: control by vaccination. Science 1982;215:1053-60.

12 MacGregor JD, MacDonald J, Ingram EA, McDonnell M, Marshall B. Epidemic measles in Shetland during 1977 and 1978. BM7 1981;282:434-6.

13 MacGregor JD. Scarlet fever in Shetland: December 1979 to April 1980. Communicable Diseases in Scotland Weekly Repon 1980; No 80/21.

14 Office of Population Censuses and Surveys. Census 1981. Workplace and transport to work. England and Wales. London: HMSO, 1984:147.

15 Alexander FE. Space-time clustering of childhood acute lymphoblastic leukaemia: indirect evidence for a transmissible agent. $\mathrm{Br} \mathcal{J}$ Cancer 1992;65:589-92.

16 Heasman MA, Urquhart JD, Kemp IW, Black RJ. Childhood leukaemia in northern Scotland. Lancet 1986;:266.

17 Heasman MA, Kemp IW, Urquhart JD, Black RJ. Leukaemia and lymphatic cancer in young people near nuclear installations. Lancet 1986;i:385.

18 Committee on the Medical Aspects of Radiation in the Environment. Second Report. Investigation of the possible increased incidence of leukaemia in young people near the Dounreay Nuclear Establishment, Caithness, Scotland. London: HMSO, 1988.

19 Miles A. Herd infection and herd immunity. In: Wilson G, Miles A, Parker MT, eds. Topley and Wilson's principles of bacteriology, virology and immunity. Vol 1. 7th ed. London: Edward Arnold, 1983:413-28.

20 Anderson RM, May RM. Population biology of infectious diseases: part 1. Nature 1979;280:361-7.

21 Black RJ, Urquhart JD, Kendrick SW, Bunch KJ, Warner J, Adams Jones D. Incidence of leukaemia and other cancers in birth and schools cohorts in the Dounreay area. $B M \mathcal{F}$ 1992;304:1401-5.

22 Bolin SR, McClurkin AW, Cutlip RC, Coria MF. Severe clinical disease induced in cattle persistently infected with noncytopathic bovine viral diarthea virus. Am $\mathcal{G}$ Vet Res 1985;46:573-5.

23 Onions DE, Jarrett $O$. Viral oncogenesis: lessons from naturally occurring animal viruses. Cancer Surv 1987;6:161-80.

24 Grant CK, Essex M, Gardner MB, Hardy WD Jr. Natural feline leukaemia virus infection and the immune response of cats of different ages. Cancer Research 1980;40:823-9.

25 Urquhart JD, Black RJ, Muirhead MJ, Sharp L, Maxwell M, Eden OB, et al. Case-control study of leukaemia and non-Hodgkin's lymphoma in children in Caithness near the Dounreay nuclear installation. BMF 1991;302:687-92.

26 Darby SC, Doll R. Fallout, radiation dose near Dounreay and childhood leukaemia. $B M \mathcal{F}$ 1987;294:603-7.

(Accepted 7 fanuary 1993) 